\title{
Alcohol self-administration by elephants
}

\author{
RONALD K. SIEGEL and MARK BRODIE \\ University of California, Los Angeles, California
}

\begin{abstract}
The anecdotal and historical literature describing intoxication in elephants from fermented fruit or alcoholic beverages is reviewed. Seven African elephants readily self-administered 7\% unflavored alcohol solutions; the results included separation from herd groupings and changes in the frequency and/or duration of several behaviors as scored according to a quantitative observational system. Alcohol decreased feeding, drinking, bathing, and exploration for most animals. Inappropriate behaviors such as lethargy and ataxia increased for all elephants. Results are discussed in terms of stress-induced drinking and intoxication.
\end{abstract}

Elephants have enjoyed a long historical association with alcohol. According to Indian mythology, a drunken elephant once spread fear and panic throughout a small Asian village, demolished houses and carts, and trampled several people. The elephant was finally calmed by none other than Buddha himself (Hackin, Huart, Linossier, De Wilman-Grabowska, Marchal, Maspero, \& Eliseev, 1963 , p. 76ff). The first elephant was brought to America in 1796 and was billed as "the most respectable animal in the world" even though it drank 30 bottles of port a day, drawing the corks with its trunk (Winfrey, 1980, p. 64). And elephant trainers and handlers regularly employ beer and other beverage alcohol as positive reinforcers for their animals (e.g., Lewis \& Fish, 1978).

This apparent preference for alcohol has produced dramatic consequences. For example, in 1974 a herd of 150 elephants broke into an illegal still and drank copious quantities of "moonshine" liquor. Intoxicated, they rampaged across West Bengal, killing 5 people, injuring 12, demolishing seven concrete buildings, and trampling 20 village huts (San Francisco Chronicle, 1974). In Africa, elephants have been known to cause widespread destruction of property in their search for and intoxication from beverage alcohol.

Not all such intoxications result from ingestion of man-made sources of alcohol. In Africa, stored grain may become wet and ferment, and the odorous molecules inevitably attract wild elephants from the surrounding forests. Despite the attempts of villagers to scare them off, these elephants come in search of the alcoholic grain (Sikes, 1971). The ripening and early natural fermentation of various fruits also signal the start of elephant migrations to these trees (Carrington, 1959;

This research was supported in part by USPHS Grant MH23880. The authors thank H. Johnson, S. Craig, M. Tennet, D. Dooley, P. Quinn, and J. Kobrin for cooperation and assistance at Lion Country Safari. The authors are affiliated with the Department of Psychiatry and Biobehavioral Sciences, School of Medicine, University of California, Los Angeles, California. Reprints are available from R. K. Siegel, Box 84358, Veterans Administration Branch, Los Angeles, California 90073.
Drummond, 1875; Sikes, 1971). Elephants ingest this fermented fruit and "after eating it become quite tipsy, staggering about, playing huge antics, screaming so as to be heard miles off, and not seldom having tremendous fights" (Drummond, 1875 , p. 223). In areas of Tanzania, bull elephants "favor" the plum-like fruit of the mgongo tree (Selerocarya caffra) and become intoxicated when it ferments in their stomachs (Sikes, 1971). This same phenomenon has been observed following ingestion of other readily fermenting fruits, such as the doum palm (Hyphaene crinita) and marula fruit (Kirkia acuminta) of southeast Africa (Usher, 1974).

Despite the abundance of these reports, there are no studies on the self-administration of alcohol or fermented fruit or grain by elephants. The apparent ease with which these animals will self-administer alcohol, in contrast to the reluctance of most other species to do so without extensive manipulations (Mello, 1973), prompts an investigation of the phenomena heretofore only anecdotally reported.

\section{METHOD}

\section{Subjects}

Three Asiatic elephants (Elephans maximus) and seven African elephants (Loxodonta africana) were used as subjects. The Asiatic elephants were born and reared in North America and had no known history of alcohol use. They were approximately $1.75 \mathrm{~m}$ in height, weighed $1,500 \mathrm{~kg}$, and were housed in a barn and maintained on a diet of alfalfa, grain, fruit, and water. The African elephants consisted of one bull (Congo) and six cows (in descending order of dominance: Nyla, Sumama, Ukali, Cita, Tano, Rafiki); they were feral born, 5-12 years of age, and 2.0-2.5 m in height. Their approximate weights were: Congo, $3,000 \mathrm{~kg}$; Nyla, 2,500 kg; Sumama, 2,000 kg; Ukali, 1,800 kg; Cita, $1,700 \mathrm{~kg}$; Tano, $1,600 \mathrm{~kg}$; and Rafiki, $1,600 \mathrm{~kg}$. These elephants were restricted to five acres of a game preserve owned and operated by Lion Country Safari, Inc., Laguna Hills, California. They had free access to a large freshwater stream, and their diet was maintained with hay, alfalfa, grain, and fruit.

\section{Apparatus}

Observations of the Asiatic elephants were made in the barn. These elephants were chained on one foreleg and one hindleg to the barn wall. The African elephants, which moved about 
freely as a herd, were observed from a vehicle positioned at different locations within the elephant preserve but usually within $10 \mathrm{~m}$ of the herd. The recording apparatus for pilot studies consisted of a plastic clipboard equipped with six Clebar 30 -min stopwatches, calibrated to $0.20 \mathrm{sec}$. The clipboard also contained a data sheet for recording frequency and duration of behavioral categories. Behaviors in the formal studies were coded in digital format with a Model DAK-8VC Datamyte portable recorder (Electro-General Corporation, Hopkins, MN). This instrument resembled a touch-tone telephone, and the observer entered behavioral codes via a 12-button keyboard. Depression of keys produced characteristic electrical signals that were automatically recorded onto a magnetic tape cartridge. A Teletype printout of raw data was later made from the tape for analysis of frequencies and durations of behaviors.

\section{Behavioral Scoring Categories}

The classification of behaviors was chosen after a review of the literature (Benedict, 1936; Carrington, 1959; Laws \& Parker, 1968; McKay, 1973; Sikes, 1971) and preliminary observations of subjects. Behaviors were chosen on the basis of their probable sensitivity to alcohol. The behaviors were recorded in terms of frequency, duration, sequence, and identity of interacting animals. The final categories of behavior are defined as: Aggression-when elephant faces target with head raised and ears extended forward or laterally, sometimes accompanied by vocalizations and pushing. Bathing-rolling in dirt, mud, or water; throwing dirt, mud, hay, or water onto body. Down-lying on side. Drinking-drawing in fluid with trunk and subsequent release into mouth. Ear flapping-extension of ears outward from the resting position snug against the head, and back again. Ear flapping occurs in bouts on a variable-interval schedule and is not continuous. Exploration-tactile or olfactory exploration with trunk. Target of trunk exploration (e.g., another elephant's trunk or mouth) is also noted. Feeding-ingestion of food but not pica. Hoarding-removal of food from vicinity of others. Head shaking-lateral jerking and swinging of head, usually coupled with ear extensions and vocalizations. Inappropriate - any unusual behavior not often seen in normal elephants. Object manipulation-manipulation of objects other than food (e.g., sticks and stones). Pushing - use of trunk, head, or body to actively move another elephant. Rock/Sway-shifting of weight from side to side or smooth rhythmic swinging of head and trunk from side to side. Rubbing - rubbing with body only. Separation-distance from nearest elephant exceeds four body lengths. Vocalization-growls, squeaks, snorts, trumpets, or other basic sounds.

\section{Pilot Studies on Alcohol Drinking}

The Asiatic elephants were used only in pilot studies to determine procedures and dosages for alcohol drinking. It was found that these elephants drew in approximately 1.75 liters of water with each trunkful and subsequently sprayed it into their mouths. Each elephant drank a minimum of 20 liters/day in this manner. Ethanol solutions in concentrations of $0 \%$, $7 \%, 10 \%, 14 \%, 25 \%$, and $50 \%$ were prepared and presented to the subjects in large calibrated buckets. It was found that $7 \%$ solutions were the highest concentrations readily and totally self-administered when water was also available ad lib. Interestingly, the $7 \%$ concentration is equivalent to the alcohol concentration found in the fermented grain eaten by elephants in Africa. When ethanol was flavored with fruit extracts, the elephants self-administered $10 \%$ concentrations, but no higher.

\section{Procedure}

Prior to alcohol sessions, the herd of African elephants was observed for a total of over $100 \mathrm{~h}$, during which time behavioral categories were developed and preliminary observations were recorded. One observer, located in a jeep, recorded the frequency and duration of behavioral postures. Observations were made for $3 \mathrm{~h}$ each day over a 2-month period during the summer. One elephant was then chosen as the target for alcohol drinking, although a different elephant was used in each alcohol session. In the final alcohol session, all elephants were given alcohol. At least 1-week intervals separated alcohol sessions.

During a given alcohol session, the designated elephant was water deprived for $12 \mathrm{~h}$ and then given free access to a large calibrated drum of $7 \%$ unflavored ethanol and allowed to drink ad lib for $30 \mathrm{~min}$, unhindered by the other animals. This resulted in an intake of as much as 75 liters. However, trunkfuls of solution were not always swallowed, but sometimes simply were sprayed on the ground or allowed to flow from the mouth. Therefore, the total dose of alcohol actually ingested could not be accurately calculated. Control sessions were conducted with plain water. Following this period, human handlers withdrew from the area, and the treated elephant was permitted access to the herd. Three hours of Datamyte observations of the treated elephant were then recorded, followed by $30 \mathrm{~min}$ of written commentary. The observer was "blind" as to whether the session was one using alcohol or water control.

\section{RESULTS}

Table 1 shows the frequency or the percentage of time each target animal engaged in selected behaviors during baseline, water, and alcohol sessions. Baseline scores were means calculated by combining baseline observations from the last $25 \mathrm{~h}$ of preliminary observations. Water and alcohol scores were means calculated by combining all observations during the 3 -h sessions. Frequency measures are expressed as mean rates per $10 \mathrm{~min}$. Percentage-of-time measures are expressed as mean percentages of time of total observation time.

During baseline observations, the elephants spent approximately $80 \%$ of observed time in the herd grouping, although this varied somewhat with dominance positions. Approximately 50\% of the time was occupied with feeding and/or drinking. The most frequently occurring behavior was exploration, and this consisted primarily of trunk-to-trunk contacts with other elephants. Ear flapping and bathing were also frequent, albeit remarkably constant for all animals, but rates increased concomitant with surrounding air temperature. The frequencies of most other behaviors, including aggression, inappropriate postures, lying down, and vocalizations, were extremely low. It is clear from Table 1 that observations during water sessions did not differ substantially from baseline. The initial introduction of the solution drum (for water or alcohol sessions) caused an increase in aggression, pushing, and exploration until the drum was withdrawn after the 30-min treatment period.

After the elephants had been treated with alcohol, dramatic changes in behavior were usually apparent within $30 \mathrm{~min}$, as is shown in Table 1. All treated elephants (except Tano) displayed increased separation time from the untreated herd, and most remained in herd groupings less than $50 \%$ of the time. Inappropriate behaviors increased for all elephants except Rafiki. These inappropriate behaviors included wrapping their trunks about themselves and both leaning and stationary 
Table 1

Behavioral Scores for Each Elephant in Baseline, Water, and Alcohol Sessions

\begin{tabular}{|c|c|c|c|c|c|c|c|c|c|c|c|c|}
\hline \multirow[b]{2}{*}{ Elephant } & \multirow[b]{2}{*}{ Session } & \multicolumn{11}{|c|}{ Behavior } \\
\hline & & $\begin{array}{l}\text { Aggres- } \\
\text { sion }\end{array}$ & $\begin{array}{l}\text { Bath- } \\
\text { ing }\end{array}$ & $\begin{array}{l}\text { Drink- } \\
\text { ing }\end{array}$ & Down* & $\begin{array}{l}\text { Ear } \\
\text { Flap }\end{array}$ & $\begin{array}{l}\text { Explora- } \\
\text { tion }\end{array}$ & $\begin{array}{l}\text { Feed- } \\
\text { ing* }\end{array}$ & $\begin{array}{c}\text { Inappro- } \\
\text { priate* }\end{array}$ & $\begin{array}{l}\text { Rock/ } \\
\text { Sway }\end{array}$ & $\begin{array}{c}\text { Separa- } \\
\text { tion* }\end{array}$ & $\begin{array}{l}\text { Vocali- } \\
\text { zation }\end{array}$ \\
\hline Congo & $\begin{array}{l}\text { Baseline } \\
\text { Water } \\
\text { Alcohol }\end{array}$ & $\begin{array}{l}.41 \\
.48 \\
.61\end{array}$ & $\begin{array}{l}1.65 \\
1.10 \\
5.72\end{array}$ & $\begin{array}{r}2.03 \\
2.21 \\
.65\end{array}$ & $\begin{array}{l}0 \\
0 \\
0\end{array}$ & $\begin{array}{l}2.69 \\
2.51 \\
4.50\end{array}$ & $\begin{array}{l}7.46 \\
5.14 \\
6.63\end{array}$ & $\begin{array}{l}55.60 \\
56.70 \\
33.01\end{array}$ & $\begin{array}{c}0 \\
0 \\
1.60\end{array}$ & $\begin{array}{l}.12 \\
.07 \\
.80\end{array}$ & $\begin{array}{l}19.27 \\
21.33 \\
55.18\end{array}$ & $\begin{array}{l}.12 \\
.15 \\
.28\end{array}$ \\
\hline Nyla & $\begin{array}{l}\text { Baseline } \\
\text { Water } \\
\text { Alcohol }\end{array}$ & $\begin{array}{l}.04 \\
.06 \\
.45\end{array}$ & $\begin{array}{r}.14 \\
1.01 \\
1.63\end{array}$ & $\begin{array}{r}10.61 \\
8.61 \\
9.24\end{array}$ & $\begin{array}{l}0 \\
0 \\
.04\end{array}$ & $\begin{array}{l}2.19 \\
2.22 \\
2.44\end{array}$ & $\begin{array}{l}8.41 \\
9.00 \\
3.31\end{array}$ & $\begin{array}{l}49.22 \\
51.89 \\
19.45\end{array}$ & $\begin{array}{l}5.93 \\
4.30 \\
9.50\end{array}$ & $\begin{array}{l}.04 \\
0 \\
.07\end{array}$ & $\begin{array}{l}16.46 \\
17.87 \\
41.64\end{array}$ & $\begin{array}{l}.53 \\
.24 \\
.72\end{array}$ \\
\hline Sumana & $\begin{array}{l}\text { Baseline } \\
\text { Water } \\
\text { Alcohol }\end{array}$ & $\begin{array}{l}.42 \\
.37 \\
.25\end{array}$ & $\begin{array}{l}3.04 \\
2.11 \\
1.18\end{array}$ & $\begin{array}{l}4.46 \\
4.98 \\
6.10\end{array}$ & $\begin{array}{l}0 \\
0 \\
0\end{array}$ & $\begin{array}{l}2.06 \\
2.13 \\
2.68\end{array}$ & $\begin{array}{l}3.87 \\
3.56 \\
3.50\end{array}$ & $\begin{array}{l}61.72 \\
56.80 \\
60.45\end{array}$ & $\begin{array}{c}0 \\
0 \\
2.60\end{array}$ & $\begin{array}{l}0 \\
0 \\
0\end{array}$ & $\begin{array}{l}19.46 \\
19.63 \\
52.11\end{array}$ & $\begin{array}{l}.17 \\
.23 \\
.10\end{array}$ \\
\hline Ukali & $\begin{array}{l}\text { Baseline } \\
\text { Water } \\
\text { Alcohol }\end{array}$ & $\begin{array}{l}.56 \\
.35 \\
.35\end{array}$ & $\begin{array}{r}1.13 \\
1.60 \\
.55\end{array}$ & $\begin{array}{l}4.36 \\
3.80 \\
1.11\end{array}$ & $\begin{array}{l}.56 \\
0 \\
0\end{array}$ & $\begin{array}{l}2.15 \\
2.44 \\
2.91\end{array}$ & $\begin{array}{l}4.18 \\
3.78 \\
4.00\end{array}$ & $\begin{array}{l}59.97 \\
52.84 \\
32.33\end{array}$ & $\begin{array}{l}0 \\
0 \\
.15\end{array}$ & $\begin{array}{l}0 \\
0 \\
0\end{array}$ & $\begin{array}{l}19.97 \\
20.41 \\
58.16\end{array}$ & $\begin{array}{l}0 \\
0 \\
0\end{array}$ \\
\hline Cita & $\begin{array}{l}\text { Baseline } \\
\text { Water } \\
\text { Alcohol }\end{array}$ & $\begin{array}{l}0 \\
0 \\
0\end{array}$ & $\begin{array}{l}1.18 \\
1.91 \\
1.10\end{array}$ & $\begin{array}{r}1.50 \\
3.79 \\
.99\end{array}$ & $\begin{array}{r}5.10 \\
.48 \\
6.70\end{array}$ & $\begin{array}{l}2.60 \\
2.39 \\
4.02\end{array}$ & $\begin{array}{l}3.77 \\
5.06 \\
4.11\end{array}$ & $\begin{array}{l}61.31 \\
59.87 \\
50.11\end{array}$ & $\begin{array}{l}6.50 \\
4.08 \\
8.84\end{array}$ & $\begin{array}{l}.35 \\
.22 \\
.50\end{array}$ & $\begin{array}{l}18.80 \\
20.22 \\
50.18\end{array}$ & $\begin{array}{l}.06 \\
.06 \\
.05\end{array}$ \\
\hline Tano & $\begin{array}{l}\text { Baseline } \\
\text { Water } \\
\text { Alcohol }\end{array}$ & $\begin{array}{l}.16 \\
.20 \\
0\end{array}$ & $\begin{array}{l}2.28 \\
2.45 \\
2.01\end{array}$ & $\begin{array}{r}8.91 \\
10.16 \\
8.98\end{array}$ & $\begin{array}{r}10.87 \\
2.10 \\
.81\end{array}$ & $\begin{array}{l}3.36 \\
2.55 \\
5.11\end{array}$ & $\begin{array}{l}4.05 \\
4.51 \\
3.00\end{array}$ & $\begin{array}{l}38.07 \\
46.10 \\
16.19\end{array}$ & $\begin{array}{l}.73 \\
0 \\
6.22\end{array}$ & $\begin{array}{l}0 \\
0 \\
0\end{array}$ & $\begin{array}{l}23.97 \\
21.00 \\
18.46\end{array}$ & $\begin{array}{l}.27 \\
.15 \\
.09\end{array}$ \\
\hline Rafiki & $\begin{array}{l}\text { Baseline } \\
\text { Water } \\
\text { Alcohol }\end{array}$ & $\begin{array}{l}.08 \\
0 \\
0\end{array}$ & $\begin{array}{l}1.45 \\
2.16 \\
1.81\end{array}$ & $\begin{array}{l}4.35 \\
4.22 \\
3.88\end{array}$ & $\begin{array}{c}2.84 \\
1.35 \\
0\end{array}$ & $\begin{array}{l}1.41 \\
2.00 \\
3.73\end{array}$ & $\begin{array}{l}3.63 \\
4.60 \\
3.00\end{array}$ & $\begin{array}{l}51.35 \\
46.10 \\
31.48\end{array}$ & $\begin{array}{l}0 \\
0 \\
0\end{array}$ & $\begin{array}{l}0 \\
0 \\
0\end{array}$ & $\begin{array}{l}33.07 \\
21.00 \\
39.16\end{array}$ & $\begin{array}{l}.23 \\
.17 \\
.12\end{array}$ \\
\hline
\end{tabular}

Note- *Scores represent mean percent time of total observation time. All other scores represent mean rates per 10 min of observation time.

postures with closed eyes. Feeding and drinking decreased for most elephants, as did bathing, exploration, head shaking, and pushing. Ear flapping increased for most animals only during the 1st hour following alcohol intake, resulting in an overall increase in this measure. Three elephants displayed an increase in rock/sway, and two of these animals, together with one other, showed increases in the amount of down time. Both the bull (Congo) and the dominant cow (Nyla) showed increased aggression and vocalizations, behaviors that decreased in frequency for the other elephants. Hoarding, head shaking, object manipulation, and rubbing did not change appreciably from baseline rates.

When the entire herd was given access to alcohol, the more dominant animals prevented Cita, Tano, and Rafiki from drinking more than 6-8 liters each, resulting in decreased alcohol intake for these elephants. Nonetheless, this procedure resulted in extremely high separation times, with animals spending between $50 \%$ and $80 \%$ of the time separated from each other. Changes in other behaviors were similar to those found during individual alcohol sessions for all elephants except Cita, Tano, and Rafiki. These animals displayed few signs of altered behavior other than increases in inappropriate behavior.

\section{DISCUSSION}

The most apparent aspect of these findings is that elephants readily drank a $7 \%$ alcohol solution in quantities sufficient to produce dramatic behavioral changes.
Although the self-administration of alcohol was not assessed in a preference situation, the alcohol sessions were not traditional forced-consumption situations. The elephants were water deprived for $12 \mathrm{~h}$ prior to the presentation of alcohol, and were presumably extremely thirsty, but the Asiatic elephants in the pilot studies consistently rejected higher concentrations of alcohol despite the water deprivation. The acceptance of the $7 \%$ solution is consistent with the range of solutions (3\%-9\%) accepted by other species such as rats and primates, which reject higher aversive concentrations (Myers \& Veale, 1972). The dosage of alcohol could not be calculated accurately but, on the basis of total fluid intake and loss, was estimated at $.50-1.00 \mathrm{~g} / \mathrm{kg}$. To the extent that this estimate is correct, the alcohol dosage here was within that range that produces symptoms of intoxication in several species (Mello, 1973).

The typical baseline behavior of these elephants was marked by feeding and drinking in the herd grouping. Following alcohol ingestion, the elephants tended to isolate themselves from the herd, spending as much as $58 \%$ of the observed time separated from others. This isolation is consistent with the reactions of numerous other species that separate from herds or social groupings following intoxication or illness (Brower \& Siegel, 1977; Siegel, 1973). Although the elephants here did not appear overly "intoxicated" or "drunk," the frequency and/or duration of specific behaviors changed dramatically. Initially, ear flapping increased, suggestive of an increase in body temperature. However, both drinking and bathing, which normally increase when elephants are hot and uncomfortable, decreased. Such decreases, coupled with decreased feeding, are more characteristic of sickness or illness in elephants.

This sickness or illness interpretation is also supported by the increase in inappropriate behaviors observed in all but one of the elephants. These behaviors included trunk wrapping (suggestive of local discomfort in the trunk) and stationary postures with closed eyes (indicative of lethargy or sleep). The possibility of central effects, supportive of intoxication per se, 
is indicated by leaning and other signs of ataxia. For Nyla and Cita, this resulted in increased rocking and swaying, as well as increased time lying down.

The dramatic alcohol-related behaviors of elephants in the wild were conspicuously absent in this study. Only Congo and Nyla displayed increased aggression during alcohol sessions, but these animals were normally the dominant and aggressive members of the herd. Furthermore, most elephants displayed only passing curiosity and exploration of the supply vehicle that dispensed the alcohol. Only Congo, following his alcohol session, pursued this vehicle and attacked one of the experimenters. Nevertheless, neither Congo nor any other elephant consumed all of the alcohol solution provided during the $30-\mathrm{min}$ sessions.

When alcohol was available to the entire herd, dominance and competition appeared to result in slightly increased consumption for four elephants but in dramatically decreased intake for three others. Nonetheless, this resulted in increased separation time and a breakdown in the herd grouping. Since competition for limited supplies of alcohol may alter intake, it remains possible that environmental stress itself may be a factor regulating alcohol intake in the wild, as it appears to be in the laboratory (Myers \& Veale, 1972). In a companion pilot study, we attempted to increase this stress by restricting the elephants here to only 2 acres of land and introducing other species such as rhinos, gazelles, zebras, and ostriches. During this period, the average consumption by Congo and Nyla during alcohol sessions increased. Nyla appeared to fall down several times, and both she and Congo displayed increased aggression and vocalizations. These findings suggest that the increase in stress in natural elephant habitats due to reductions in range forests and increases in herd density and mortality may be important variables in explaining the concomitant increased intake of alcoholic fruits and beverages. An important caveat is that the present study failed to control nonpharmacological variables (e.g., nutrition, calories, taste, and smell), which may be equally important factors in the control of the self-administration of alcohol by elephants.

\section{REFERENCES}

Benedict, F. (1936). The physiology of the elephant. Washington, D.C: Carnegie Institution of Washington.

Brower, K., \& Siegel, R. K. (1977). Hallucinogen-induced behaviors of free-moving chimpanzees. Bulletin of the Psychonomic Society, 9, 287-290.

Carrington, R. (1959). Elephants. New York: Basic Books.

DRUmmond, W. H. (1875). The large game and natural history of South and Southeast Africa. Edinburgh: Edmonston \& Douglas.

Hackin, J., Huart, C., Linossier, R., De Wilman-GrabowSKa, H., Marchal, C.-H., Maspero, H., \& Eliseev, S. (1963). Asiatic mythology. New York: Crowell.

Laws, R. M., \& Parker, I. S. C. (1968). Recent studies on elephant populations of East Africa. Symposia of the Zoological Society of London, 21, 319-359.

LEWIS, G., \& FISH, B. (1978). I loved rogues. Seattle: Superior.

McKay, G. M. (1973). Behavior and ecology of the Asiatic elephant in Southeastern Ceylon (Smithsonian Contributions to Zoology, No. 125). Washington, D.C: Smithsonian Institution Press.

Mello, N. K. (1973). A review of methods to induce alcohol addiction in animals. Pharmacology, Biochemistry and Behavior, 1, 89-101.

MYers, R. D., \& Veale, W. L. (1972). The determinants of alcohol preference in animals. In B. Kissin \& H. Begleiter (Eds.), The biology of alcoholism: Vol. 2. Physiology and Behavior (pp. 131-168). New York: Plenum Press.

San Francisco Chronicle (1974, July 29).

Siegel, R. K. (1973). An ethologic search for self-administration of hallucinogens. International Journal of Addictions, 8, 373-393.

Sikes, S. (1971). The natural history of the African elephant. London: Weidenfield \& Nicolson.

Usher, G. (1974). A dictionary of plants used by man. London: Constable.

Winfrey, P. (1980). The unforgettable elephant. New York: Walker. 